Original Research Article

\title{
Islamic-Content-TED Public Speaking as a Source Material for Improving Islamic Student's Communication Skill
}

\author{
Lyla Anggerwina Kusuma \\ Sekolah Tinggi Ilmu Dakwah Al-Hadid Surabaya, Jl Kejawan Putih Tambak no 80 Surabaya, \\ East Java, Indonesia \\ Article history: Received 10 September 2017 ; Accepted 2 October 2017 ; Published 10 October 2017
}

\begin{abstract}
In applying communicative competence that became the utmost teaching method in teaching English program, the lecturers found the fact that the Islamic communication students are apparently reluctant to speak and communicate their ideas confidently. It happens because they thought that they do not know what they are going to say and how they are going to say their ideas. By knowing these problems the lecturers then tried to analyze the sequences of Islamic-content-TED and integrate those public speaking sequences from TED talks to STID Al-Hadid's students to give an understanding and also to improve the confidence and quality in delivering public speaking speech for the sophomore students who are majoring Islamic Communication \& Broadcasting. For further, in order to master this skill, students are also expected to find noble ideas to be shared in their personal public speaking. This action research study then found out that having sharing the sequences of TED talks, the student's public speaking productions are more organized and powerful; moreover, the fluency and also the student's accuracy of the students could be controlled well.
\end{abstract}

Keywords: CLT; ESP; KPI; public speaking; TED talk

HOW TO CITE: Kusuma, L.A. (2017). Islamic-Content-TED Public Speaking as a Source Material for Improving Islamic Student's Communication Skill. JEES (Journal of English Educators Society), 2(2). 75-90. doi:http://dx.doi.org.10.21070/jees.v2i2.1007

\section{Introduction}

In this last decade, the growth of Islamic Universities and Institutes accessed from forlap dikti is steeply increasing. It proves that most Indonesian people have more interest to join Islamic Universities in continuing their higher education. One of the favorite major in dakwah faculty that is offered by those Islamic Universities and Institutes is Islamic Communication and Broadcasting Major (KPI/Komunikasi Penyiaran Islam). Islamic Communication and Broadcasting Major is a study about how to do dakwah / propagate the Islamic value to the society through a range media. Mostly, the target competence of this major is the ability in delivering, communicating, and propagating the idea of Islam, as the consequences the communication skill becomes important skill that should be mastered by

E-mail address: lyla.kusuma@gmail.com

Peer reviewed under reponsibility of Universitas Muhammadiyah Sidoarjo.

(C) 2017 Universitas Muhammadiyah Sidoarjo, All right reserved, This is an open access article under the CC BY license (http://creativecommons.org/licenses/by/4.0/) 
Islamic College Students from KPI students as stated in Islamic University vision and missions.

On other sides, Islamic university students who are mostly from Islamic schools or conventional Islamic boarding house have a different paradigm about learning English, compared to the vision and mission of Islamic Universities. The unique thing is those conventional Islamic boarding houses have characteristic that focuses on Arabic Language and Middle East Culture rather than English Language and Western Culture. As the consequences, based on the English Language pretest result taken by the lecturer, the students apparently see English skill as a minor skill that does not really need to be achieved since they understand the goal of attending in Islamic boarding house is to have good morality and be able to build a better society in their neighborhood. Because of this paradigm, they are reluctant to learn, speak and master English Language. To achieve the vision and mission of Islamic university and to minimize the gap between University target and freshmen's paradigm on English, this article aims to find the effective way to train students speaking skill by using English public speaking skill theory via Islamic-content TED Talks (Technology Entertainment Design Talk).

TED (Technology, Entertainment and Design) Talks has been providing intellectually stimulating presentations since 1984. TED presentations are delivered by non-native and native speakers of English. This TED talks has downloadable transcripts that are available in over 40 languages via the TED website. Many educators have been utilizing these valuable learning materials since there are a lot of things could be explored from TED Talks. These talks are valuable for education for many reasons (Carlo, 2014; Denskus \& Esser, 2015; Rubenstein, 2012; Sugimoto \& Thelwall, 2013; Taibi et al., 2015). It provides the availability of linguistic support with the innovative and engaging content, and also with the clarity of the presentation structure.

Most of research on English Public Speaking, by TED, are mostly focusing their research into experiential and theoretical descriptions (Chen, 2010; Jing \& Li, 2009; Yuan, 2000; Ren, 2007; Jing-lan \& Hui, 2006; Coxhead \& Walls, 2012). However, some of the studies lack theoretical support and there were only few studies that provide complete and systematic lesson planning and models to follow. In the integration of TED in English Language Teaching (ELT), most of the researches mostly focus only on listening skill (Rost, 2011; Wolfe, 2013) and less integrate the TED talks for improving speaking skill. This 
Original Research Article

Islamic-Content-TED Public Speaking as a Source Material for Improving Islamic Student's Communication Skill

Lyla Anggerwina Kusuma

research then aimed to; (1) use the TED Talks as authentic materials (2) figure out the steps of integrating public speaking sequences from TED talks to STID Al-Hadid's students in order to give an understanding of public speaking roles; (3) assimilate the language and ideas from Islamic-content TED videos for their personal public speaking; (4) improve the confidence and English quality in delivering public speaking speech for the sophomore students who are majoring Islamic Communication \& Broadcasting by using Islamic-content TED Talks in step-by step-lesson plans.

TED Talks were used as supplementary materials to teach oral communication, presentations and public speaking skills for Islamic Broadcasting and Communication Students (KPI) at STID Al-Hadid, Indonesia. The selected TED Talks which have Islamic content, later is called Islamic-content TED Talks, were used as an authentic material in the classroom as demanded by Communicative Language Teaching (CLT) approach which is aimed to develop students' listening and speaking skills in English, to provide any topics, themes, or non-language issues of interest that meets the Content Based Instruction (CBI) criteria and to provide a contextual presentations for Islamic Students.

\section{Methods}

In this section, the rationale for integrating action research will be addressed. The rationale of integrating action research for this study is to see the process of systematic collection and the analysis of data in order to make an improvement of students's speaking skill. Nunan said that the classroom could be a laboratory for experimenting and evaluating the materials and classroom tasks in a teacher's own context and situation (Nunan, 1991). For further he and some researchers stated that this form of action research that is very significant in language education and promoted classroom action research to be applied in all levels of education, especially university level, where the teachers could become the researcher and have more authorities to create language curriculum. (Nunan, 1992; Warrican, 2006).

The design of this research is based on the concept of promoting students' confidence, accuracy, and proficiency in speaking English by using action research procedures to investigate how their confidence in speaking could be improved through the implementation of Islamic-TED Talks as a source material for Islamic Communication and Broadcasting Students. The data were obtained by using both quantitative and qualitative methods. This research had accomplished 4 main stages in each cycle, there are Planning stage, Action and Observation stage, Reflection stage and Revision stage. 


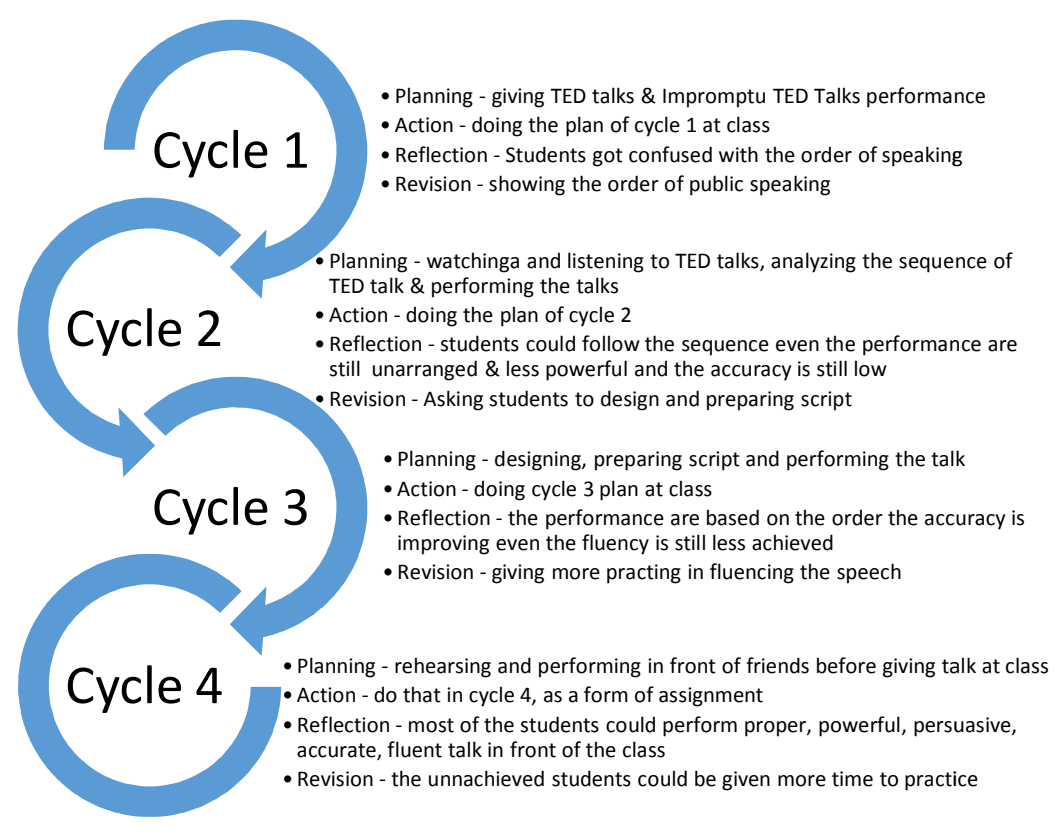

Figure 1. Action Research Cycles

\section{Findings and Discussion}

\section{English and Islamic-TED Talk}

English subject in KPI major in fact becomes one of the fundamental subjects to be given to the students in order to prepare them to face the globalization era. In this globalization era, they should be able to understand the Islamic ideas and communicate their Islamic values either in active or passive English. Whenever they work as a news anchor or journalist in national or local television stations for example they should have capability in understanding both national and international issues especially that are related to Islam. They also have to be literate in understanding, using, pronouncing specific terms that are closely related to Islam, such as the issue of Islamophobia, Islamic bigotry issues, woman oppression by using hijab and many other Islamic issues. By seeing those characteristics, In English Language teaching (ELT) this specific Purpose of English Teaching for Islamic Broadcasting and Commination Learners is Classified as ESP teaching as classified by Dudley-Evans \& St John (1998).

"TED Talks" which is known as talks for Technology, Entertainment and Design is a private, non-profit organization founded in order to disseminate "ideas worth spreading". The Talks which are delivered by non-native and native English speakers have downloadable transcripts that are available in over 40 languages via the TED website. These talks are 
Original Research Article

Islamic-Content-TED Public Speaking as a Source Material for Improving Islamic Student's Communication Skill

Lyla Anggerwina Kusuma

distributed under a Creative Commons license and are thus free for English Trainers to utilize these valuable and accessible these authentic learning materials in their classes ${ }^{1}$. The TED website has two features that make it particularly useful for language teaching. The first is an interactive transcript for each video in the original English as well as many other languages, all translated by volunteers with clickable phrases that allow students to jump directly to that particular phrase in the video, and the subtitles, which, in addition to being a great language study support, can also help students to grasp the conceptual content of the presentations in order to participate in class activities.

As mentioned before, many educators incorporate TED Talks into their lessons and TED Talks have found their way into nowadays culture. This makes TED Talks as one of excellent ESL teaching aides and below would be described some benefit for both the instructor and the student in incorporating TED as listening tools, authentic materials, vocabulary boosters and speaking teaching tools in EFL classroom.

The importance of listening skill in EFL classrooms is hardly ever developed well since most educators think that it is passive skill and secondary to speaking (More \& Carreon, 2012; Graham, 2009). Listening in EFL Classroom was apparently mostly presented as listening testing activities rather than listening training activities. Non authentic listening materials probably contribute to the failure of listening development. According to Rost (2011) the recommended listening materials presented in the classroom should be intensive, interactive, extensive, responsive and autonomous. The listening material should have phonology, grammar and vocabulary target as demanded in intensive listening. The ability of determining main ideas and gist should be considered in choosing selective listening materials. The materials should also be interactive because it could stimulate the active learning in listening class. Listening material should be able to be presented as a listening for pleasure and also academic in the same time. Responsive listening could be understood as the stand of listener's point of view. Last but not least, Listening materials should be able to be chosen autonomously by the learners. TED Talks could certainly be used for all types of listening described by Rost (2011).

As Harmer (2007) said, the authenticity is best described, as any text that has not been created specifically for language learning or simply, text designed for native speakers. Morrow (1977) also understand it as any listening materials that is from real language and produced by a real speaker or writer for a real audience and designed to convey a real 
message. In general, authentic materials provide a more source of lexical and syntactic input for students to "notice", are more beneficial to develop students' communicative competence (Gilmore, 2007, and increase student motivation (Clavel-Arroitia \& Fuster-Marquez, 2014; Peacock, 1997). Since TED Talks are given to audience of English speakers and also tend to bring popular issues, the writer then could classify TED Talks as authentic materials. Moreover, the characteristic defined by Morrow (1977) also strengthen the idea of TED Talks as an excellent authentic material for English learners.

The fact that by having more vocabularies, learners would have easier understanding of the target language that becomes a main reason of important role of vocabularies in both first and second language acquisition across all levels of education. In order to compile proper Islamic vocabulary lists gathered from Islamic-content TED Talks as authentic materials, this research have analyzed high-frequency words across the selected Islamic TED corpus and some of the results that were used into the classroom for eliciting student's understanding about the selected Islamic-content TED Talks in listening and pre activity for speaking section could be seen on the table below.

\section{The steps of integrating Islamic-content TED Talks for Islamic Broadcasting and Communication Students (KPI)}

\section{- Cycle 1}

In this cycle, the lecturer introduced the form of Islamic TED talks to the students and asked the students to perform the TED talk based on the targeted sequences. The language focus had been prepared by the lecturer. The goal of this cycle was introducing the type of TED Talks, getting the main idea from the talk based on the table below.

Table 1. The Islamic-English TED material for cycle 1

\begin{tabular}{|l|l|l|l|}
\hline Presenters & $\begin{array}{l}\text { Language Focus } \\
\text { Discuss the meaning of the } \\
\text { vocabularies / phrases in } \\
\text { bold with your partner }\end{array}$ & $\begin{array}{l}\text { Comprehension } \\
\text { Questions } \\
\text { Discuss the content of } \\
\text { selected TED Talks with } \\
\text { your group }\end{array}$ & $\begin{array}{l}\text { Discussion } \\
\text { Questions } \\
\text { Give your opinions of } \\
\text { selected TED Talks } \\
\text { with your group }\end{array}$ \\
$\begin{array}{l}\text { Mustafa Akyol } \\
\text { in Islam versus Tradition }\end{array}$ & $\begin{array}{l}\text { I put on my ritualistic dress } \\
\text { I observed all the rituals. } \\
\text { They were together while } \\
\text { doing the circular walk } \\
\text { around the Kaaba. }\end{array}$ & $\begin{array}{l}\text { 1. What event that happens in } \\
\text { the Story Mustafa tells at } \\
\text { the start of the talk? } \\
\text { 2. What were two important } \\
\text { messages delivered by } \\
\text { Akyol? }\end{array}$ & $\begin{array}{l}\text { Aave you ever been } \\
\text { in a similar } \\
\text { condition to the one } \\
\text { Akyol describes in } \\
\text { story at the }\end{array}$ \\
& $\begin{array}{l}\text { beginning? } \\
\text { 2.Can you find similar } \\
\text { issue happen in } \\
\text { Indonesia? }\end{array}$ \\
\hline Attiya Latif & $\begin{array}{l}\text { I've struggled with divisive } \\
\text { stereotypes that threaten my }\end{array}$ & $\begin{array}{l}\text { What happened when } \\
\text { Attiya was at school? }\end{array}$ & $\begin{array}{l}\text { What do you think } \\
\text { of the talk? }\end{array}$ \\
\hline
\end{tabular}




\begin{tabular}{|c|c|c|c|}
\hline $\begin{array}{l}\text { TEDxUVA } \\
\text { A Feminist's Choice to } \\
\text { Wear the Hijab }\end{array}$ & $\begin{array}{l}\text { identity as a human being } \\
\text { the term haja which literally } \\
\text { means to conceal or hide from } \\
\text { view } \\
\text { that means being humble in } \\
\text { your daily } \\
\text { this idea of modesty is often } \\
\text { seen as outmoded or } \\
\text { primitive people }\end{array}$ & $\begin{array}{l}\text { 2. What is her conception } \\
\text { of her belief about } \\
\text { Hijab? } \\
\text { 3. What did she do to solve } \\
\text { her problems? }\end{array}$ & $\begin{array}{l}\text { 2. Have you ever } \\
\text { been in a similar } \\
\text { situation to the one } \\
\text { Attiya describes in } \\
\text { her story? } \\
\text { 3. What did you do? }\end{array}$ \\
\hline $\begin{array}{l}\text { Yassmin Abdel- } \\
\text { Magied } \\
\text { What does my } \\
\text { headscarf mean to you? }\end{array}$ & $\begin{array}{l}\text { Equal opportunity is } \\
\text { ubiquitous } \\
\text { Bias does not determine our } \\
\text { lives } \\
\text { What we're doing here is } \\
\text { identifying and } \\
\text { acknowledging that a bias } \\
\text { exists } \\
\text { There's an intense lack of } \\
\text { diversity in our places }\end{array}$ & $\begin{array}{l}\text { 1. Who is Yasmin Abdeel? } \\
\text { 2. What is the unconscious } \\
\text { bias that she meant in } \\
\text { her talk? } \\
\text { 3. What is her suggestion } \\
\text { to the ones who want to } \\
\text { see and be wise in } \\
\text { seeing diversity? }\end{array}$ & $\begin{array}{l}\text { 1. What do you think } \\
\text { of the unconscious } \\
\text { bias in the talk? } \\
\text { 2. Have you ever } \\
\text { been in a similar } \\
\text { situation to the one } \\
\text { Yasmin describes } \\
\text { in her story? How } \\
\text { does it happen to } \\
\text { you? } \\
\text { 3. Does unconscious } \\
\text { bias happen in } \\
\text { Indonesia? } \\
\text { 4. What kind of } \\
\text { unconscious bias } \\
\text { happens in } \\
\text { Indonesia? }\end{array}$ \\
\hline $\begin{array}{l}\text { Dalia Mogahed } \\
\text { What it's like to be } \\
\text { Muslim in America }\end{array}$ & $\begin{array}{l}\text { Do you look at me as an } \\
\text { oppressed, brainwashed } \\
\text { woman? } \\
\text { That's just how the media has } \\
\text { been portraying people who } \\
\text { look like me } \\
\text { My feminist friends were } \\
\text { aghast: "Why are you } \\
\text { oppressing yourself?" } \\
\text { I wrestled with the Quran } \\
\text { You are Middle-Eastern } \\
\text { descent } \\
\text { a prominent imam told me a } \\
\text { story that really took me aback }\end{array}$ & $\begin{array}{l}\text { 1. What is the issue that } \\
\text { was raised by the } \\
\text { speaker? } \\
\text { 2. How was the perception } \\
\text { of most American } \\
\text { whenever they see } \\
\text { woman with headscarf? } \\
\text { 3. What is her suggestion } \\
\text { to solve the security } \\
\text { issue in America? }\end{array}$ & $\begin{array}{l}\text { 1. What do you think } \\
\text { about the talk? } \\
\text { 2. Do you think the } \\
\text { speaker was } \\
\text { oppressed by } \\
\text { wearing Hijab? } \\
\text { Why? } \\
\text { 3. Do you think } \\
\text { terrorism issue } \\
\text { happen in } \\
\text { Indonesia? } \\
\text { 4. How do } \\
\text { Indonesian People } \\
\text { see the issue of } \\
\text { Islamophobia and } \\
\text { terrorism? }\end{array}$ \\
\hline $\begin{array}{l}\text { Amal Kassir } \\
\text { The Muslim on the } \\
\text { airplane }\end{array}$ & $\begin{array}{l}\text { International spoken word } \\
\text { poet } \\
\text { Unapologetic Muslim } \\
\text { woman } \\
\text { Activist } \\
\text { Social justice advocate } \\
\text { A terrorist } \\
\text { A sand nigger } \\
\text { A raghead, oppressed } \\
\text { A suspect } \\
\text { A radical } \\
\text { An extremist }\end{array}$ & $\begin{array}{l}\text { 1. What does her name } \\
\text { mean? } \\
\text { 2. What happen to her at } \\
\text { the beginning of her } \\
\text { story? } \\
\text { 3. How do most people see } \\
\text { the refugees? } \\
\text { 4. According to Amal, } \\
\text { what should we do with } \\
\text { our curiosity? }\end{array}$ & $\begin{array}{l}\text { 1. What do you } \\
\text { think about the } \\
\text { talk? } \\
\text { 2. What do you } \\
\text { think about the } \\
\text { way she delivers } \\
\text { her talk? } \\
\text { 3. How should we } \\
\text { act on our } \\
\text { curiosity? } \\
\text { 4. What would we } \\
\text { do to face our } \\
\text { fear? }\end{array}$ \\
\hline
\end{tabular}


The materials above had been used by Islamic Broadcasting and Communication students in the classroom. The target of this 1 st cycle was the introduction of those 5 selected Islamic-content TED talks into the class for 1-2 meetings. Having watched the students were asked to answer all those questions in class with their friends, besides, they were also introduced by the new vocabularies that are closely related with Islamic theme. The students were asked to listen one of those TED talks and figure out the important sequences in those talks based on Gallo's public speaking sequences (2014). This activity has a purpose to improve students' intensive listening skill by noticing the general idea of the materials. The students are also expected to be responsive in seeing the issue by giving comments / point of view on the presented listening this activity was good for stimulating student's critical thinking.

Having done the 1st activity, the students were asked to present the classroom activity result in the form of formal presentation and performing the selected Islamic-TED topic as presented by the 5 presenters above. This presentation was regarded as the 1 st time for the students to present TED Talk like in front of the class. in this presentation, the performances of the students were assessed by the public speaking rubric as explained in method section.

From the presentation result, teacher noticed that almost all students did not have any idea in structuring TED public speaking talk. The thing that could be appreciated was the courage and confidence of the students in presenting their presentation with Islamic selected topic given. Most of the students did great job in integrating the targeted vocabularies into their presentation.

\section{- Cycle 2}

Having reflected the result of cycle 1, the teacher set a target in making students understand on public speaking sequence. The students were given second worksheet that had been specially created by the lecturers to figure out the style and major sequences presented in those selected Islamic-content TED Talks. Before that, the lecturer introduced one IslamicContent TED Talks in the title "Islamophobia killed my brother, let's end the hate" by Suzanne Barakat and give the public speaking theory and analyze the talks based on TED Talks sequences presented by Gallo (2007). The sequences were presented in the table below, and the students were asked to analyse the other Islamic talks in the form of group then present the result and present the sample of the talk in front of the class. 
Table 2. Islamic-English TED Talk Analysis sequence for cycle 2

\begin{tabular}{|l|l|l|l|}
\hline Presenter & $\begin{array}{l}\text { Emotional } \\
\text { How do they open their talk? } \\
\text { What is this opening? } \\
\text { How do you feel about their } \\
\text { opening? } \\
\text { Are their verbal delivery and } \\
\text { their body language comfortable } \\
\text { and impactful for you? }\end{array}$ & $\begin{array}{l}\text { Novel } \\
\text { What is the talk about? } \\
\text { Was the speaker easy to } \\
\text { Understand? } \\
\text { What is the message? }\end{array}$ & $\begin{array}{l}\text { Memorable } \\
\text { What do you } \\
\text { think about the } \\
\text { speaker? } \\
\text { What can you } \\
\text { remember most } \\
\text { from the } \\
\text { speaker? }\end{array}$ \\
\hline $\begin{array}{l}\text { Mustafa Akyol } \\
\text { Faith versus Tradition } \\
\text { in Islam }\end{array}$ & & & \\
\hline $\begin{array}{l}\text { Attiya Latif } \\
\text { TEDxUVA } \\
\text { A Feminist's Choice to } \\
\text { Wear the Hijab }\end{array}$ & & & \\
\hline $\begin{array}{l}\text { Yassmin Abdel- } \\
\text { Magied } \\
\begin{array}{l}\text { What does my } \\
\text { headscarf mean to you? }\end{array}\end{array}$ & & & \\
\hline $\begin{array}{l}\text { Dalia Mogahed } \\
\text { What it's like to be } \\
\text { Muslim in America }\end{array}$ & & & \\
\hline $\begin{array}{l}\text { Amal Kassir } \\
\text { The Muslim on the } \\
\text { airplane }\end{array}$ & & & \\
\hline
\end{tabular}

In this cycle, the students were targeted to understand the component of public speaking. The basic components of communication theory coined by Aristotle were known as the existence of ethos, logos, and pathos in persuasive skill. Ethos is the speaker credibility, logos is known as the evidence or data and pathos is the emotional appeal that should be presented to persuade audience. Gallo (2014), simplified those Greek theory into the sequences of TED Talks. The sequences of TED Talks should cover; (1) Emotional / Ethos the presentation should touch the audience heart; (2) Novel / Logos - the presentation should teach something new; (3) Memorable / Pathos-the audience should never forget the presentation.

Being emotional means the speaker should attached their emotion of their topic to the audience. The attachment could be created by exhibiting great presentation style, body language, and verbal delivery to make the listener feel comfortable and impactful. Novelty becomes the most important aspect in TED talks. TED presenter should engage the audience by giving something new and sharing new information by using unique approach to the area 
of their study. Some memorable TED presentations come from the vivid presentation and multisensory experiences felt by the audience. In order to get the understanding of being emotional, Novel and Memorable, KPI Students are asked to analyze the selected Islamiccontent TED materials and present the result in front of the class as the 2nd assignment. Having accomplished this part of learning, the students are expected to get the idea of logos, pathos and ethos or to understand the flow of TED Talk that should be Emotional, Novel, and Memorable. So, in the next session, the students could create their genuine and powerful public speaking in the form of Islamic TED Talks. Below is the worksheet given for analyzing the flow of selected Islamic talks.

\section{- Cycle 3 and 4}

The third and fourth cycle was the case building of the personal Islamic TED Talks by the students. The students were asked to autonomously choose the theme / social issues that that they want to raise make a concept of their Islamic TED talks by following the sequences of TED Talks proposed by Gallo (2014). The third cycle focused on preparing the novelty of their presentation material and the fourth cycle focused on giving the pathos and ethos for their material by rehearsing or doing the preparation of presentation in front of their chosen friends; the students should work in small group and present the material in front of them, and then get the feedback from them. The goal of the last cycle was the preparation for their presentation as the rehearsal for their future final test.

The role of TED Talks used for improving speaking skill is not as plenty as improving speaking skill. Most researchers use any TED Talks to help students with their pronunciation. These talks may serve as an excellent model from which students can practice individual words, thought groups, word stress, etc. Students could use the word by word listening input / "Micro-listening" materials by practicing reproducing these new words at home. Besides practicing the micro-listening skill in the form of practicing pronunciation, in this section, the students got a worksheet that consist of the flow and sequences of TED Talks compiled from the official TED guide to public speaking and Gallo's sequence for powerful TED Talks.

The students are asked to design their Islamic public speaking presentation by following the guide below. As Gallo (2014) and Anderson (2016) said in his Official TED guide, TED Public Speaking should cover three main aspect of presentation, they are introduction / Emotional (Pathos) section, Content / Idea which is known as Novel (Logos), and the last is closing or Memorable section (Pathos) in Gallo's definition. The first focus on building / designing this presentation is preparing the novel idea that would be presented to 
Original Research Article

Islamic-Content-TED Public Speaking as a Source Material for Improving Islamic Student's Communication Skill

Lyla Anggerwina Kusuma

the audience. Anderson (2016) defined an idea as anything that can change how people see the world. By conjuring up a compelling idea in people's minds, the TED Public Speakers have done something wondrous by giving the audiences a gift of incalculable value for their life. The issue or idea should not be big / had thing to understand, it could be started from the simple thing we know / master about. The point is an important idea, wrapped up in a fresh story, can make a great talk, if it's told the right way. As a reason of religious weekly sermons that tell us the same things over and over, packaged different ways. In this section, KPI students could start sharing simple Islamic idea such as the point of view of being modest by wearing hijab, the equality concept in Islam as seen in pilgrimage ritual in mecca, etc.

Having done the content, the students were asked to design their public speaking in their ethos and pathos sequence as demanded in assignment 4. In opening / pathos / emotional section, the students should pick the way to open the Islamic TED Talks and set the verbal delivery and their body language while presenting the material. The presenter could tell anecdotes relevant to your subject matter, start the opening with the quotation or delivering unforgettable moment related to the material. If the students want to wrap their Islamic TED Talks into more academic, they could start giving statistical data or comparison of one to another of particular issue they raised. After designing the powerful and emotional opening, the students should give attention on the verbal delivery and body language. The verbal delivery covers the rate (speed in which we speak), volume (the loudness and softness), pitch (high or low inflection), and pauses (short pauses to punch keywords) during presentation and enthusiasm, eye contact, communicative body language, meaningful gestures in body language section. The speaker could prepare the appropriate gesture and expression in particular line of their speech such as nodding the head when the speaker say "Yes, no one would be treated differently", or leaning the body forward by opening palms for introducing $\operatorname{him} /$ her, and many others.

In closing section, the presenter could give multi-sensory experience by using multimedia for activating visual sense, integrating powerful delivery \& sounds for giving memorable auditory experience and bringing props or doing kinesthetic sense for touching the audience feeling. The presenter cold duplicate the way Yassmin Abdel take of her Abaya to show her other Muslim "face"/ "wardrobe", an engineering cloth, whenever he work in oil rig site to activate audience visual and kinesthetic sensory. The last is the way to close the Islamic TED Talks. The students could give Call to action / Personal Commitment / Values 
and Vision / Satisfying Encapsulation / Narrative Symmetry / Lyrical Inspiration to end with power.

Table 3. The Islamic-TED Talk-Like Design for cycle 3 and 4

\begin{tabular}{|c|c|c|}
\hline 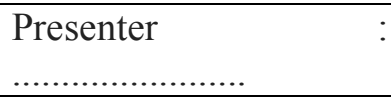 & Class: ............................ & Topic: ............................... \\
\hline \multicolumn{3}{|c|}{ 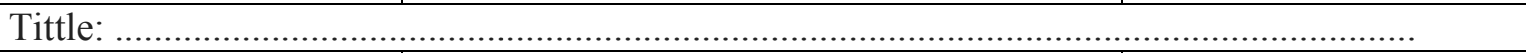 } \\
\hline & & $\downarrow \downarrow$ NOTES $\downarrow \downarrow$ \\
\hline \multicolumn{3}{|c|}{ Emotional (Ethos) } \\
\hline Opening & $\begin{array}{l}\text { Deliver a dose of drama by using Anecdote } \\
\text { / Narration / Story / Quotation / Definition } \\
\text { Ignite Curiosity by giving comparration / } \\
\text { Statistical Data } \\
\text { Show a compelling slide, video or object } \\
\text { Teasing audience }\end{array}$ & \\
\hline Verbal Delivery & Rate, Volume, Pitch, Pauses & \\
\hline Body Language & $\begin{array}{l}\text { Enthusiasm, Eye contact, Communicative } \\
\text { body language, Meaningful gestures }\end{array}$ & \\
\hline \multicolumn{3}{|c|}{ Novel (Logos) } \\
\hline New Information one & $\begin{array}{l}\text { Supporting Points } 1.1 \\
\text { Supporting Points } 1.2 \\
\text { Supporting Points } 1.3 \\
\end{array}$ & \\
\hline New Information one & $\begin{array}{l}\text { Supporting Points } 1.1 \\
\text { Supporting Points } 1.2 \\
\text { Supporting Points } 1.3 \\
\end{array}$ & \\
\hline New Information three & $\begin{array}{l}\text { Supporting Points } 3.1 \\
\text { Supporting Points } 3.2 \\
\text { Supporting Points } 3.3 \\
\end{array}$ & \\
\hline \multicolumn{3}{|c|}{ Memorable (Pathos) } \\
\hline $\begin{array}{l}\text { Multi-Sensory } \\
\text { Experience }\end{array}$ & $\begin{array}{l}\text { Multimedia (visual) / Powerful delivery \& } \\
\text { sounds (auditory) / Kinesthetic sense \& } \\
\text { props (feel) }\end{array}$ & \\
\hline Stay on your lane & The Signature "I am ..." & \\
\hline Closing & $\begin{array}{l}\text { Call to action / } \\
\text { Personal Commitment / } \\
\text { Values and Vision / } \\
\text { Satisfying Encapsulation / } \\
\text { Narrative Symmetry / } \\
\text { Lyrical Inspiration }\end{array}$ & \\
\hline
\end{tabular}

After public speaking training, students showed remarkable improvement at the end of the semester. Having accomplished all cycles's activities in the form of assignments and tasks in one semester, most of the students could improve the content of talk and the way to present their material persuasively. The accuracy, the pronunciations and the fluency especially were also improved well. As the data showed from the bar below, the students' 
achievement were improving. From cycle one, most students achieve the good level and the enc of the cycle, most of the students, 33 out of 52 students could achieve the very good level and $10 \%$ of them could achive the excellent shore in the last cycle. Generally, from the presented graph this paper showed that the very good level of the student could be achieved gradually.

\section{Graph 1. The cycle result}

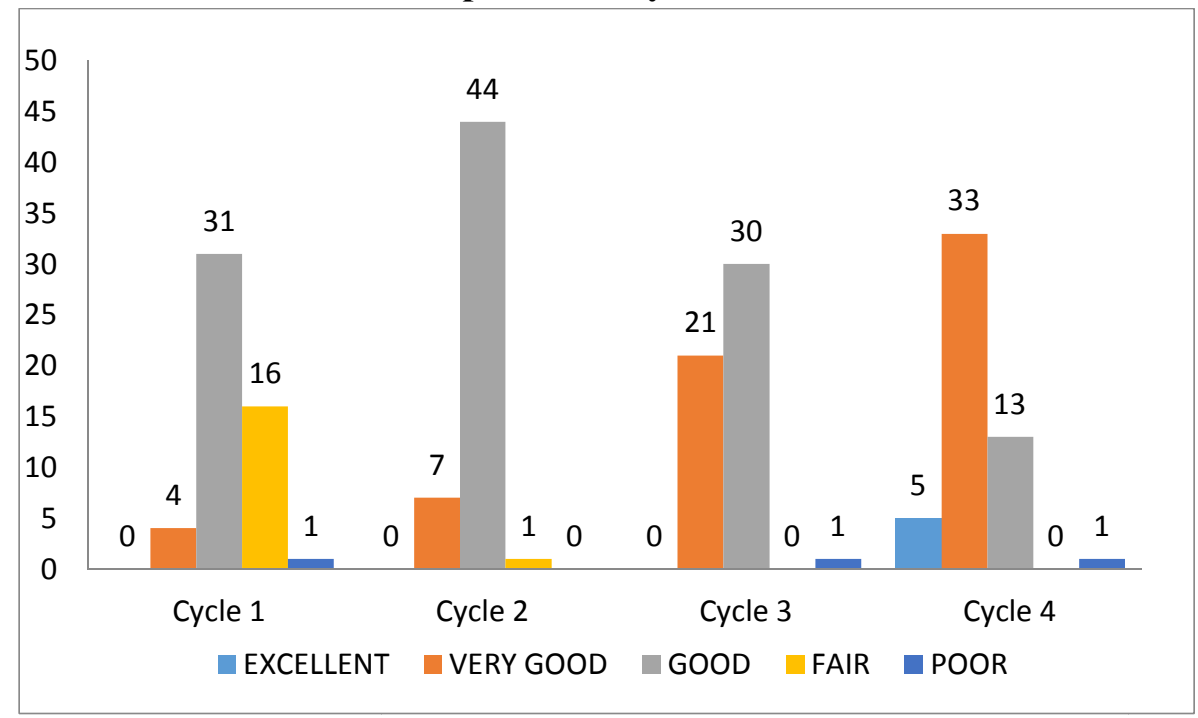

\section{Conclusions}

This article highlighted important advantages and steps gained through the use of Islamic-content TED Talks as authentic materials in Islamic Broadcasting and Communication EFL classroom. This integration could cultivate further interest in the specified field or topic that can eventually lead to more autonomous and meaningful learning for not only listening skill but also speaking skill. By utilizing the language, ideas, and sequences of Islamic-content TED videos for students' personal public speaking, as the result, students showed remarkable improvement at the end of the semester. Not only have they improved the confidence in delivering English-Islamic content TED Talks, but they also have improved their accuracy, pronunciation, and fluency. Further research must be conducted to determine the effectiveness TED has in improving speaking skill among undergraduate university students.

\section{Acknowledgments}

This research was supported by STID Al-Hadid especially the Islamic Communication and Broadcasting department. I am thankful to Ms Lina Masruuroh, the 
leader of KPI major, who had kindly given her expertise and valuable suggestions throughout this research. I would also like to give my special gratitude to all my Islamic Communication and Broadcasting students year 2016-2017 who inspired me to integrate TED talk as a source material in this English 2 subject.

\section{References}

Anderson, C. (2016). TED Talks: The Official TED Guide to Public Speaking. Boston: Houghton Mifflin Harcourt.

Chen, L. (2010). Strategies on Contents, Activities and Evaluations in Public Speaking Courses. Foreign Languages Research.

Clavel-Arroitia, B., \& Fuster-Marquez, M. (2014). The authenticity of real texts in advanced English language textbooks. ELT Journal, 68(2), 124-134. https://doi.org/10.1093/elt/cct060

Coxhead, A. J., \& Walls, R. (2012). TED Talks, Vocabulary, and Listening for EAP. The Journal of the TESOL Association of Aotearoa New Zealand, 20, 55-67.

Dudley-Evans, T., \& St John, M. J. (1998). Developments in English for Specific Purposes: A Multi-Disciplinary Approach. Cambridge: Cambridge University Press.

Gallo, C. (2014). Talk Like TED: The 9 public-speaking secrets of the world's top minds. New York: Macmillan.

Gilmore, A. (2007). Authentic materials and authenticity in foreign language learning (Vol. 40, p. 97). Cambridge University Press. https://doi.org/10.1017/S0261444807004144

Graham, S. (2009). Review of the book Listening in the language classroom. System, 37, 540-541. https://doi.org/10.1016/j.system.2009.05.004

Harmer, J. (2007). The practice of English language teaching. London: Pearson Longman.

Jing-lan, Y., \& Hui, J. (2006). A Tentative Approach to the Study of English Public Speaking and Students Integrated Ability. Journal of East China University of Science and Technology (Social Science Edition).

Jing, W. H., \& Li, W. P. (2009). A Study of the Relationship between English Public Speaking Curriculum and the Integrated Ability of Foreign Language Talents. Foreign Languages and Their Teaching, 9(2), 42-45.

More, S. H., \& Carreon, J. R. (2012). Hidden Challenges that Radio DJs Present to ESL/EFL Listeners. LEARN, 5, 19-29. Retrieved from https://social.tcithaijo.org/index.php/learn/article/view/1000181

Morrow, K. (1977). Authentic texts and ESP. In Holden. In English for specific purposes. Modern English Publications (pp. 13-15).

Nunan, D. (1991). Language Teaching Methodology: A Textbook for Teachers. Englewood Cliffs: Prentice Hall. 
Nunan, D. (1992). Research Methods in Language Learning. Cambridge: Cambridge University Press.

Peacock, M. (1997). The effect of authentic materials on the motivation of EFL learners. ELT Journal, 51(2), 144-156. https://doi.org/10.1093/elt/51.2.144

Ren, W. (2007). English Public Speech Teaching and Development of Comprehensive Abilities. Foreign Languages in China, 4(6).

Rost, M. (2011). Teaching and researching listening (2nd ed.). Harlow, U.K: Longman.

Warrican, S. J. (2006). Action research: A Viable Option for Effecting Change. Journal of Curriculum Studies, 38(1), 1-14. https://doi.org/10.1080/00220270500175537

Wolfe, J. (2013). TEDucation: Input and Output; 2 Ways of Using TED Talks in the Language Classroom. In Proceedings from The Asian Conference on Technology in the Classroom. The International Academic Forum (IAFOR). Aichi, Japan.

Yuan, X. F. (2000). On the Function and Value of English Public Speaking Teaching. Journal of South-Central University for Nationalities (Humanities and Social Science), 20(3). 
Journal of English Educators Society, 2 (2), October 2017, 75-90

ISSN 2503-3492 (Online)

Journal Homepage: http://ojs.umsida.ac.id/index.php/jees

DOI Link: http://doi.org.10.21070/jees.v2i2.1007 